\title{
A BUSINESS MANAGEMENT MODEL OF TENNIS TRAINING CENTER: AN ANALYTICAL ISSUE ${ }^{1}$
}

Pairin PANJASILPA ${ }^{2}$
Received Date (Başvuru Tarihi): 01/08/2018
Accepted Date (Kabul Tarihi): 15/08/2018
Published Date (Yayın Tarihi): 02/09/2018

\begin{abstract}
This article aims to present knowledge from the literature review of business management model of tennis training center in Thailand, as well as to describe the meaning and background of elements and relationships of variables related to the business management model. From the literature review, it was found that the popular variables include corporate image, quality of service, marketing mix for service (7Ps), satisfaction and loyalty.
\end{abstract}

Keywords: Management Model, Training Center, Tennis

JEL Codes: I21, L22

\section{TENIS EĞİTIMİ MERKEZI İÇİN YÖNETIM PLANI: ANALITTIK BİR YAKLAŞIM}

ÖZ

Bu çalışmanın amacl, Tayland'daki tenis ĕgitim merkezlerinde uygulanan yönetim planlarına dair yapılmış çalışmaları incelemek ve yanısıra, yönetim planına ilişkin faktörlerin temelini ve değişkenler arasındaki ilişkiyi araştırarak sunmaktır. Yapılan literatür taramasında, en popüler değişkenlerin kurumsal imaj, hizmet kalitesi, pazarlama karması (7p), doyum ve sadakat olduğu belirlenmiştir.

Anahtar Kelimeler: Yönetim Modeli, Eğitim Merkezi, Tenis

JEL Kodlart: I21, L22

\footnotetext{
${ }^{1}$ This article presented "The 4th International Conference on Management, Business, and Economics \& The 6th International Conference on Tourism, Transport, and Logistics Congress"

${ }^{2}$ DBA S., Sripatum University, Bangkok- Thailand, PositiveThinking_PositiveLife@ hotmail.com https://orcid.org/0000-0002-8046-4264
} 


\section{INTRODUCTION}

In the present day, a number of countries have encourages people to excel and participate in sports. Countries that have developed sports as career ways, have proven to be extremely beneficial since the sport business provides huge economic growth to all nations. In addition, developing sports into careers is also indicative of the progress of the countries (Pairin, 2013). The Thai government has continuously been focusing on the development of professional sports as seen from every national sport development plan in the first edition (1988 - 1996) No. 2 (1997 - 2001) No. 3 (2002-2006) No. 4 (2007-2011) No. 5 (2012 - 2016) and No. $6(2017$ - 2021). These clearly define the objectives and goals in creating careers from sports by developing the following 12 sports into the professional sports: four types of team sports (football, sepa takraw, volleyball and basketball) and 8 types of individual sports (golf, tennis, snooker, bowling, badminton, table tennis, motor racing and boxing). These are professional sports that have the global standards in professional sports policy to develop the country's potential international equivalent, focus on sports management, and boosting investment in sports development by encouraging the private sector to see the benefits of sports development and investment, such as tax policy, and to support the quality of life of personnel and organizations involved in the Thai sport industry. One thing that is important for the development of professional sports is that professional athletes must be capable and qualified by international standards. Thus, they will be popular with viewers and supporters. Sponsors and professional sports centers must apply marketing mixed management, product or competition field, price, promotion, public relations, etc., in order for the development of professional sports to be successful (Ministry of Tourism and Sports).

In 2002, tennis was one of the most popular sports in Thailand due to the outstanding performance of Paradorn Srichaphan and Tamarind Thanasukarn. Both of them made over ten million baht a year from playing professional tennis tournaments. Paradorn Srichaphan climbed the professional tennis rankings from over 100 to 11 in one year, making a name for himself and increasing the popularity of tennis in Thailand. This can be seen in the dramatic increase in the number of younger tennis players competing in the juniors competition organized by the Lawn Tennis Association of Thailand. 700 players were added in 2002 and 1,500 in 2003 (Supit Samahito, et al., 2004). "Paradorn of Fencing", was also the first tennis player to become the world's No.9 at the age of 24, on May 12, 2003. For this reason, the Tennis Training Center in Thailand is managed by both public and private sectors, but mostly the latter. They are organized by tennis players' experience from beginner to advanced level and organized by experienced tennis instructors. This is the same throughout the country; because younger tennis 
players have turned their attention to tennis. According to Ornuch Gomdee (2007), many sports center have turned their attention to tennis academy or tennis training center, both in Bangkok and other provinces.

It has been almost 14 years since the popularity of tennis in Thailand has increased; yet there has been no Thai tennis player as successful as Paradorn Srichaphan. The tennis training center has an unclear management system. According to Paradorn, the Thai tennis industry has to spend a lot more time to create "Super Ball 2" due to a number of obstacles including the management system of the organization, coaching system, and lack of sponsors. Most importantly, the athletes themselves lack commitment and motivation. (Siam Sports, 2018). In order to develop professional tennis players in the long run, there has to be an Asian Tennis Training Center and a standardized tennis center (Suphit, Samahito, et al, 2004).

There is no clear evidence of who created or brought tennis to Thailand and when. It is assumed that tennis was started in the reign of King Chulalongkorn by the British and Americans who came to Thailand. Thai noblemen and high officials started playing the sport around those times. Some of them dressed in purple while chewing betel on courts. On the other hand, it was typical for foreigners to wear white trousers, which were considered more polite than short pants. After a while, Thais who played tennis started adapting the same tradition. People didn't pay much attention to tennis until 1917. His Majesty the King showed interest in the sport and founded the Lawn Tennis Association of Thailand on April the 14th, 1927, with the help of 12 tennis clubs including the Rajgithia club, the English club, Samakkham Athletic Club, Nakhonsawan Club, Silom Club, Lampang Club, Nawarat State Club, Chiang Mai Gym Club, Cana Songkhla Club and Defense Club Phuket. The delegates attended the meeting for the first time at the Palace Department of Pisces. They unanimously voted to set up the "Lawn Tennis Association of Thailand" and His Majesty the King was the first Lawn Tennis Association president. The rules and norms of the Association have been used up to this day. (Poompitak, 2017).

The problems mentioned above have sparked the curiosity of many researchers, leading them to study the factors that influence the business of tennis training center. There have been studies on the appropriate styles of tennis business management in Thailand in terms of private sector. They are more flexible in terms of management than government agencies, where there are more obstacles, from rules to budget. The results of this research will be used as guidelines for promotion and application, to develop and improve tennis business management in Thailand, to satisfy customers' needs, influencing users' loyalty, as well as to promote the standard of tennis business center in Thailand. 


\section{Research Objectives}

Research Business management model of tennis center in Thailand The objectives of the study are as follows.

1) To study the factors affecting successful tennis training center business in Thailand.

2) To study the influence of factors on tennis training center business success in Thailand.

3) To develop the business management model of the Tennis Training Center in Thailand.

\section{Research Scope}

\section{Academic Benefits}

1) To determine the factors influencing tennis business center to improve and develop tennis sport in Thailand to be effective.

2) To design a business management model suitable for Thailand.

\section{Business Benefits}

1) It is a guideline for the government to use the standard of tennis training center business in Thailand.

2) It is a guideline for tennis business executives to improve the management of tennis training center business in Thailand to be effective and efficient

\section{Research Hypothesis}

Business management model of tennis training center in Thailand. The research hypothesis is as follows.

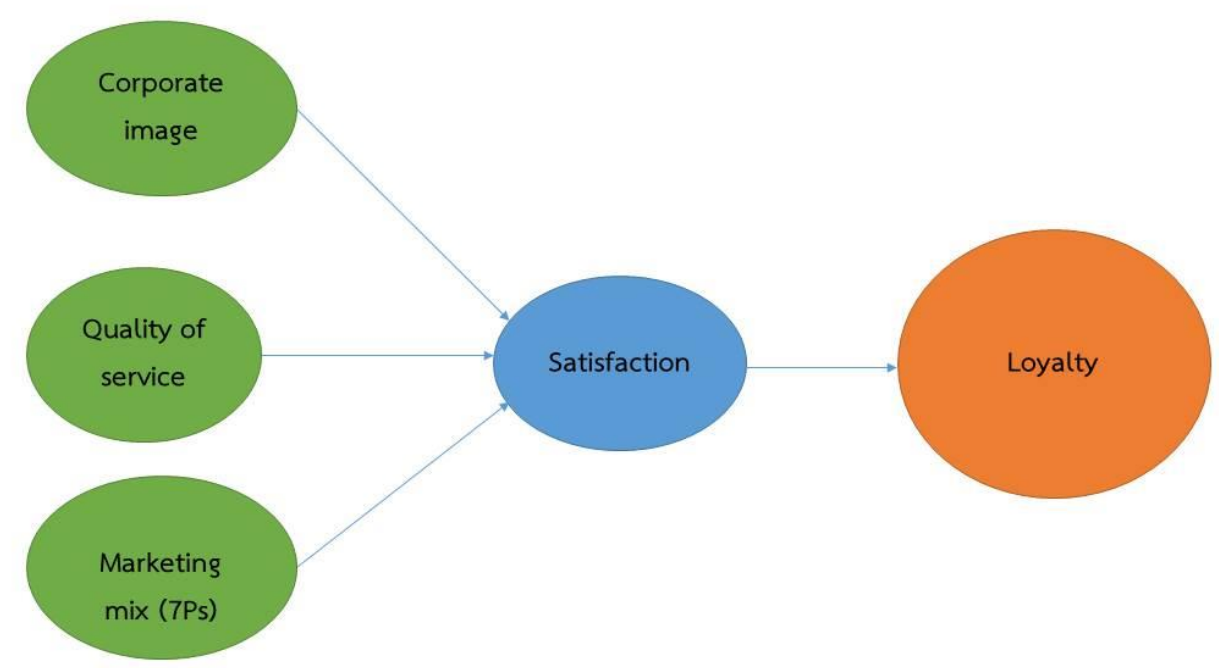




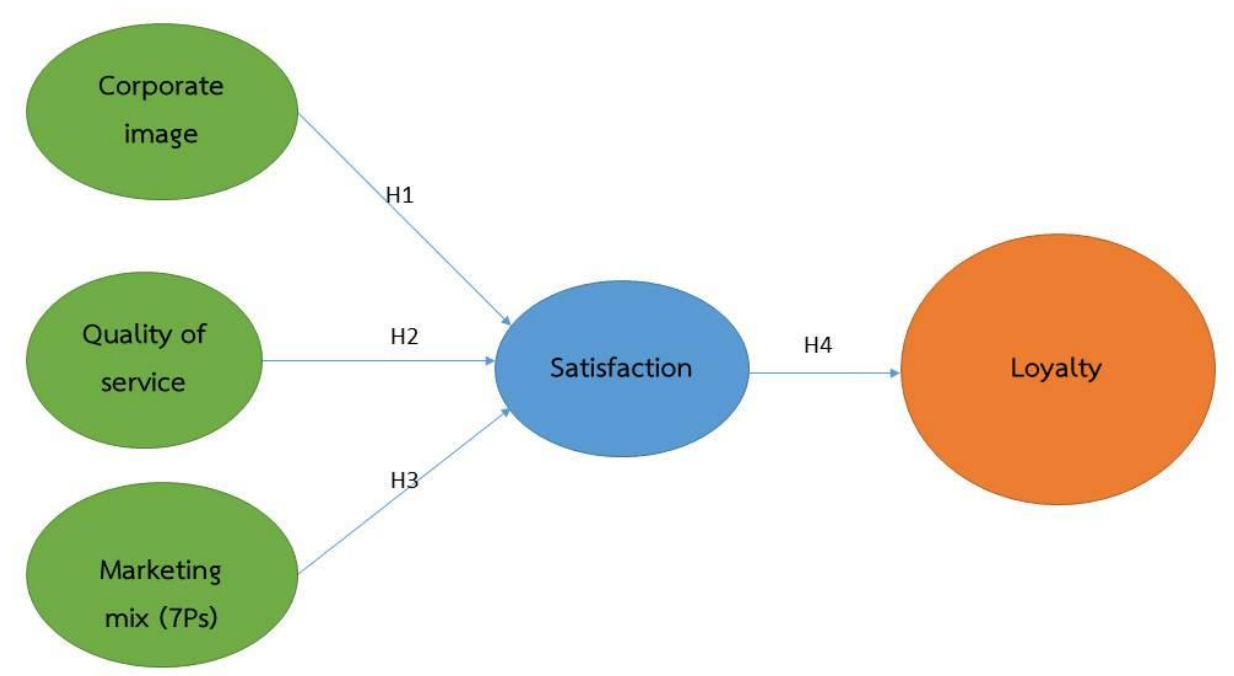

Figure 1: Research Hypothesis

Hypothesis 1: Corporate image Direct influence on satisfaction.

Hypothesis 2: Quality of service Direct influence on satisfaction.

Hypothesis 3: Marketing mix (7Ps) has direct influence on satisfaction.

Hypothesis 4: Satisfaction has a direct influence on loyalty.

\section{LITERATURE REVIEW}

Corporate Image represents the image of the customer's mind in the tennis business. This includes the management of goods and services in accordance with the article by Charles J. Fombrun (1996), Jaichansukkit (2002), Stan et al. (2013) and Satyendra (2015). It consists of 3 elements.

1. CEO means the image of the manager. He must be trained, be ethical, with innovative vision and management approach in order for business to grow.

2. Staff means the employees. They must have a good attitude and personality, as well as being capable of developing relationship, being responsible, honest and have the service mind.

3. Service means the corporate image. It must be fast, qualified and meet the advertised message.

Quality of service reveals that every customer is always satisfied when using the Tennis Training Center. It includes the consumer's mind, impression, satisfaction, and loyalty. 
In accordance with Berry et.al (1986), George (2013), Chen (2016) and Amin (2016), it consists of 5 elements:

1. Reliability means the ability to provide services in accordance with the contract provided to the recipient. Every service must be accurate and effective at all points of service. This consistency will make the service provider feel that the service is reliable.

2. Responsiveness refers to readiness and willingness to serve. It can meet the needs of customers in a timely manner. Service can be easily accessed, making it convenient to use. The service must be distributed thoroughly and quickly.

3. Confidence refers to the ability to build trust with the recipient. Service providers must demonstrate knowledge skills. The ability to provide services and meet the needs of the service is along with gentleness, politeness, and good courtesy by using effective communication and ensuring that the recipient receives the best service.

4. Access to services means the location of a service and availability of the service provider in order to facilitate the service.

5. Touchable service means the ability to care about the recipient in accordance with the different needs of each recipient.

Marketing mix (7Ps) refers to the factors that affect service intentions. According to Booms and Bitner (1981), Kotler (2000), Schuckert (2012) and Smith (2015), it consists of 7 elements.

1. Product refers to the factors that the consumer attach importance to the service, including the type of service provided.

2. Price means the value of service in the form of money. Consumers will compare prices to the value of services that they receive.

3. Place refers to the location and channel. Channels are the structures used to move the service from the organization to the market.

4. Promotion means the tool that is used for communication between distributors and consumers.

5. Person means a teacher or service officer in a tennis practice center. Service people must be qualified and trained to be able to satisfy customers' needs in different ways from competitors. Teachers or staff need to be knowledgeable.

6. Physical Evidence and Presentation refers to the quality of the physical conditions and the service to provide value to the user.

7. Process means activities related to the method and practice in providing services to users. Being able to provide accurate and fast service will result in customers' satisfaction. 
Satisfaction refers to the consumers' perception of the use of the tennis center. The user compares the expectations with the recognition of operating results. Customer satisfaction is based on their experience in using the Tennis Training Center. Customers that have a positive attitude towards the tennis center are in accordance with the articles of Ofir and Simonson (1960), Tjien (2012), Kim et al. (2014), Goda (2016) and Multafa (2016). It consists of 3 elements.

1. Expectation refers to the anticipation of the service. The more they use the service, the higher their expectation is.

2. Experience refers to the knowledge of the previous customers' experience from media, finding information, making decision of whether to use the service, and telling others about it, or to continue using the service.

3. Attitude means the feeling of the user is expressed as a behavior. When they enjoy the service they will show it in accordance with their existing attitudes.

Loyalty refers to loyal customers who display two behaviors: repurchase and word-ofmouth recommendations, which will influence the perception of quality and satisfaction that has occurred before. It is caused by the effectiveness and positive interaction with the service provider. According to Oliver (1999), Darke (2006) and Mazzarol (2015) it consists 2 elements.

1. Intentional use refers to the purchase decision or service to the original manufacturer that comes from the satisfaction of the product and service as a result of the initial decision that may be caused by both internal and external factors in the consumer itself.

2. Word of mouth means the formal communication of the qualities of the organization or service, in which the communication results in more people trusting the service.

\section{Research Framework}

From the above literature review, the researcher designed the business management model of Tennis Center in Thailand successfully. External latent variables include corporate image, quality of service and marketing mix (7Ps). Internal latent independent variable consists of satisfaction and the dependent variable is loyalty. Each component displays the image. 


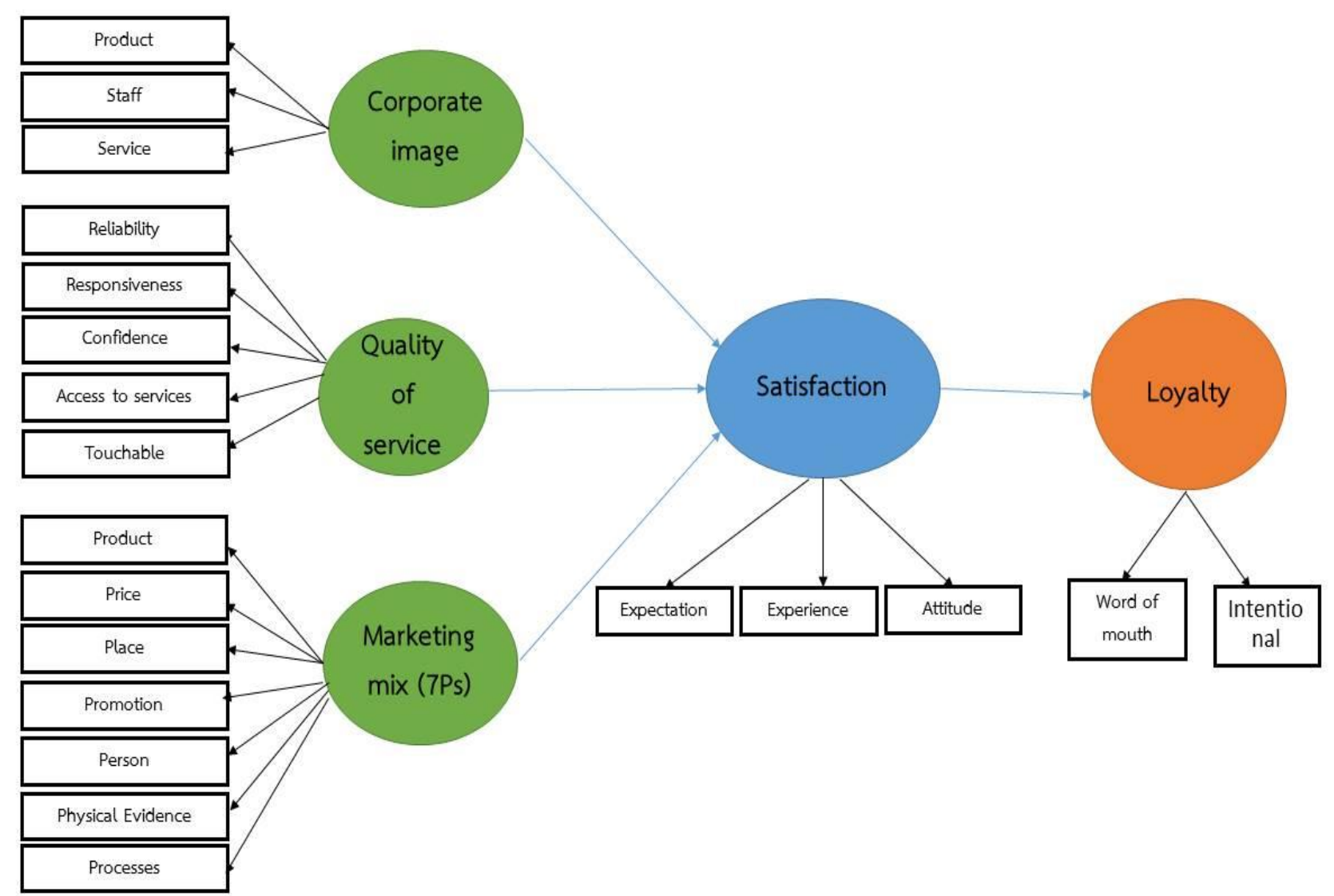

Figure 2: Research Framework

\section{Relationship between variables}

Researcher has found satisfaction from corporate image. Quality of service and the marketing mix (7Ps) will affect loyalty.

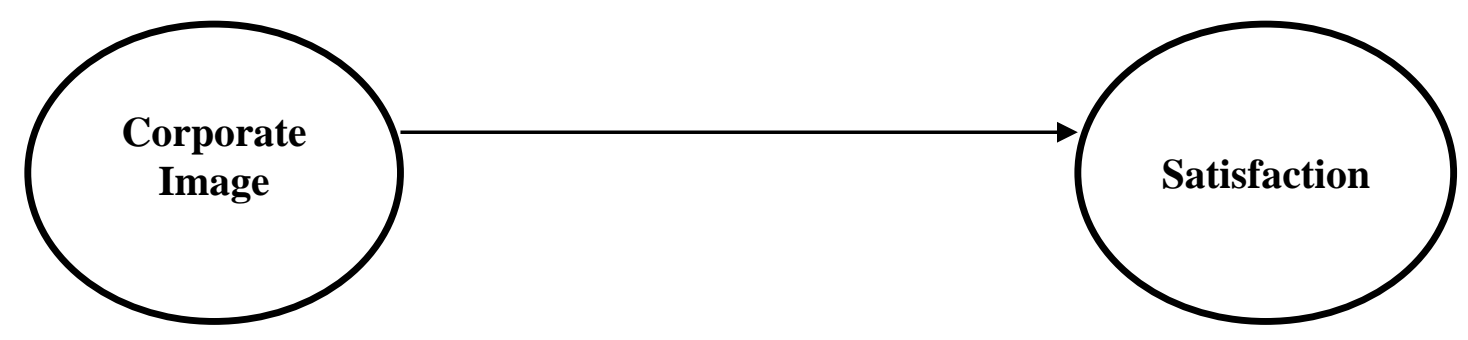

Figure 3: Corporate Image Direct Affects On Satisfaction

Figure 3 illustrates the effect of corporate image on satisfaction that is in accordance with research by Charles J. Fombrun (1996). Good corporate image should consist of three components: the CEO, the Staff, and the Service. This is in line with Satyendra's (2015) study of the success of corporate image management. It is a mechanism to drive the organization to achieve its goals and have a sustainable value. Similarly, Stan et al. (2013) studied the costeffectiveness of switching to third-party service providers in developing customer loyalty and 
found that image in customer perspective and quality of service. The service has a significant relationship with customer loyalty and Jaichansukkit (2002) found that corporate image is what was collected and evaluated by customers who came to use the service.

\begin{tabular}{lccc}
\hline \multicolumn{1}{c}{$\begin{array}{c}\text { Reference } \\
\text { (Name of Researcher / Year) }\end{array}$} & CEO & STAFF & SERVICE \\
\hline Charles J. Fombrun (1996) & $\checkmark$ & $\checkmark$ & $\checkmark$ \\
\hline Jaichansukkit (2002) & $\checkmark$ & $\checkmark$ & $\checkmark$ \\
\hline Stan et al. (2013) & $\checkmark$ & $\checkmark$ & $\checkmark$ \\
\hline Satyendra (2015) & $\checkmark$ & $\checkmark$ & $\checkmark$ \\
\hline
\end{tabular}

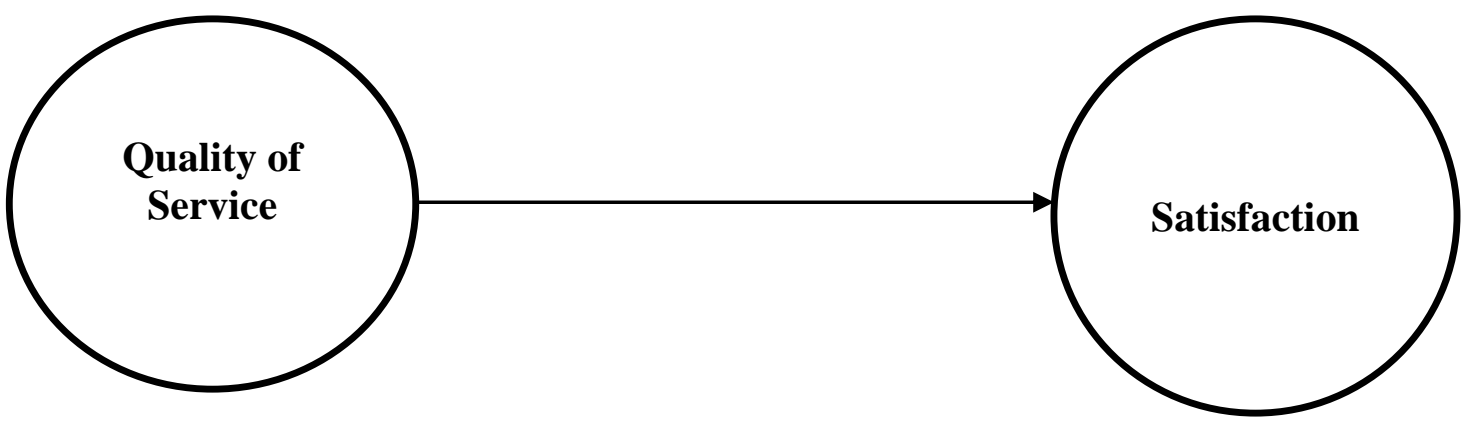

Figure 4: Quality Of Service Affects On Satisfaction

Figure 4 reviews the effect of quality of service on satisfaction. Berry et.al (1986), found that service quality should have five main components: reliability, responsiveness, confidence, access to services. As for George (2013), five components of service quality will affect customer satisfaction in the US cinema service, parallel with the study of Amin (2016), where he studied the quality of service, definition of satisfaction and customer loyalty. Research has revealed that the relationship between service quality, customer satisfaction and customer loyalty is important to the sports training center and Chen (2016) found that maintaining a superior service quality over competitors by offering the quality of service as expected, affects customer satisfaction.

\begin{tabular}{|c|c|c|c|c|c|}
\hline $\begin{array}{c}\text { Reference } \\
\text { (Name of Researcher / Year) }\end{array}$ & Reliability & Responsiveness & Confidence & $\begin{array}{l}\text { Access to } \\
\text { services }\end{array}$ & Touchable \\
\hline Berry et.al (1986) & $\checkmark$ & $\checkmark$ & $\checkmark$ & $\checkmark$ & $\checkmark$ \\
\hline George (2013) & $\checkmark$ & $\checkmark$ & $\checkmark$ & $\checkmark$ & $\checkmark$ \\
\hline Chen (2016) & $\checkmark$ & $\checkmark$ & $\checkmark$ & $\checkmark$ & $\checkmark$ \\
\hline Amin (2016) & $\checkmark$ & $\checkmark$ & $\checkmark$ & $\checkmark$ & $\checkmark$ \\
\hline
\end{tabular}




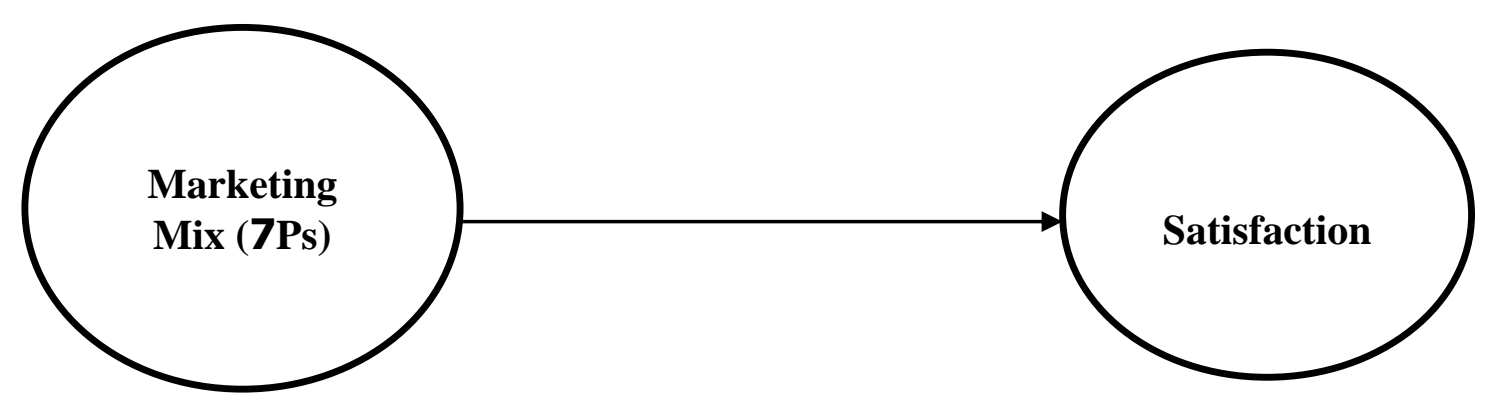

Figure 5: Marketing Mix (7ps) Affects On Satisfaction

According to Figure 3, the marketing mix (7Ps) has a direct effect on satisfaction. Booms and Bitner (1981) and Kotler (2000) study the findings. Service Marketing Mix is a concept that deals with business services, which are different businesses, consumer goods and general consumer goods. The marketing mix (7 Mixes) or 7Ps (7 Mixes) is divided into 7 categories: Product, Price, Place, Marketing Promotion (Promotion) Physical Evidence and Presentation, and Process, in accordance with Schuckert's (2012) research, which examines the factors that influence the success of an amusement park. By gathering relevant literature to determine the factors that influence the success of the amusement park and use the research methodology, the researcher interviewed by the amusement park management in Austria, Germany and Switzerland and found that the marketing mix (7Ps) was the most significant factor in the success of the theme park, and Smith (2015) studied the marketing mix (7Ps) that contributed to the level of user satisfaction of subway service in New York State, The United States The research found that Marketing Mix Directly influence the customer satisfaction. The marketing mix (7Ps) was developed by McCarthy (1964), who created the concept of marketing mix (4Ps), namely product, price, place and promotion.

\begin{tabular}{|c|c|c|c|c|c|c|c|}
\hline $\begin{array}{c}\text { Reference } \\
\text { (Name of Researcher } \\
\text { / Year) }\end{array}$ & Product & Price & Place & Promotion & Person & $\begin{array}{l}\text { Physical } \\
\text { Evidence }\end{array}$ & Process \\
\hline McCarthy (1960) & $\checkmark$ & $\checkmark$ & $\checkmark$ & $\checkmark$ & & & \\
\hline Booms and Bitner (1981) & $\checkmark$ & $\checkmark$ & $\checkmark$ & $\checkmark$ & $\checkmark$ & $\checkmark$ & $\checkmark$ \\
\hline Kotler (2000) & $\checkmark$ & $\checkmark$ & $\checkmark$ & $\checkmark$ & $\checkmark$ & $\checkmark$ & $\checkmark$ \\
\hline Schuckert (2012) & $\checkmark$ & $\checkmark$ & $\checkmark$ & $\checkmark$ & $\checkmark$ & $\checkmark$ & $\checkmark$ \\
\hline Smith (2015) & $\checkmark$ & $\checkmark$ & $\checkmark$ & $\checkmark$ & $\checkmark$ & $\checkmark$ & $\checkmark$ \\
\hline
\end{tabular}




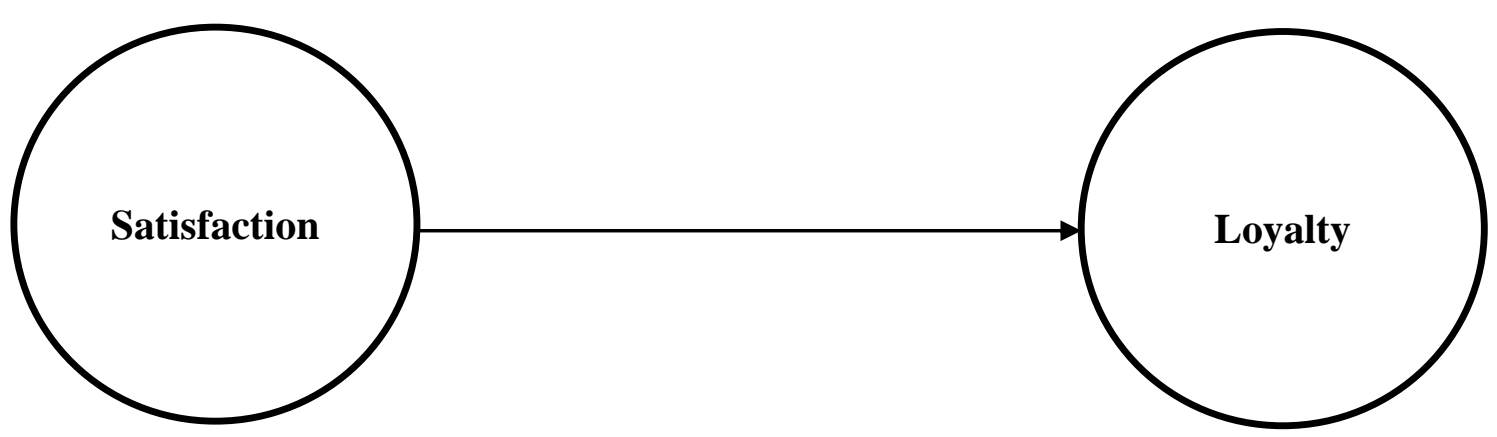

Figure 6: Satisfaction Affects On Satisfaction Loyalty

Figure 4, reveals that satisfaction has a direct effect on loyalty, as it is the same according to Ofir and Simonson (1960) and Tjien (2012). Expectations and experiences are components of achieving Satisfaction according to Kim et al. (2014). The acquired experience becomes an attitude that is a component of satisfaction. An attitude influences the intention to return to buy or tell others about the customer service and it is parallel with Multafa's research (2016) that studies the relationship between satisfaction and loyalty in the Malaysian tourism industry. The results confirm that loyalty and satisfaction are positively correlated. It is very important to the visitors in Malaysia. The results of this study are consistent with the findings of other researches. Therefore, it can be concluded that the Malaysian tourism industry must strategically strive to achieve satisfactory results in order to create loyal customers. Because satisfaction has a huge impact on customer intentions, maintaining customer base is like a promise to tell and it also encourages repeat purchases (Goda 2016). When consumers have a positive attitude, it leads to behavioral use. If they are satisfied, it will lead to repeat service habits. The result will be brand loyalty, positive relationship and customers will to use the service regularly.

\begin{tabular}{lccc}
\hline \multicolumn{1}{c}{$\begin{array}{c}\text { Reference } \\
\text { (Name of Researcher / Year) }\end{array}$} & Expectation & Experience & Attitude \\
\hline Ofir and Simonson (1960) & $\checkmark$ & $\checkmark$ & $\checkmark$ \\
\hline Tjien (2012) & $\checkmark$ & $\checkmark$ & $\checkmark$ \\
\hline Kim, et al. (2014) & & & $\checkmark$ \\
\hline Goda (2016) & $\checkmark$ & & $\checkmark$ \\
\hline Multafa (2016) & $\checkmark$ & & \\
\hline
\end{tabular}

\section{DISCUSSION}

From the literature review, the conceptual model is anticipated to be suitable for business management in Thailand. Satisfaction and loyalty have a positive impact on the success of the Tennis Training Center in Thailand. The organization's image is composed of the CEO, the staff, and the service, reliability, accessibility, service, and touchable service. The 
marketing mix (7Ps) consists of product, price, place, promotion, people, creation and presentation of physical characteristics. Physical Evidence and Presentation, and 3 Latent Processes will affect the loyalty of the users as well as successful management of tennis business center in Thailand.

\section{FUTURE RESEARCH}

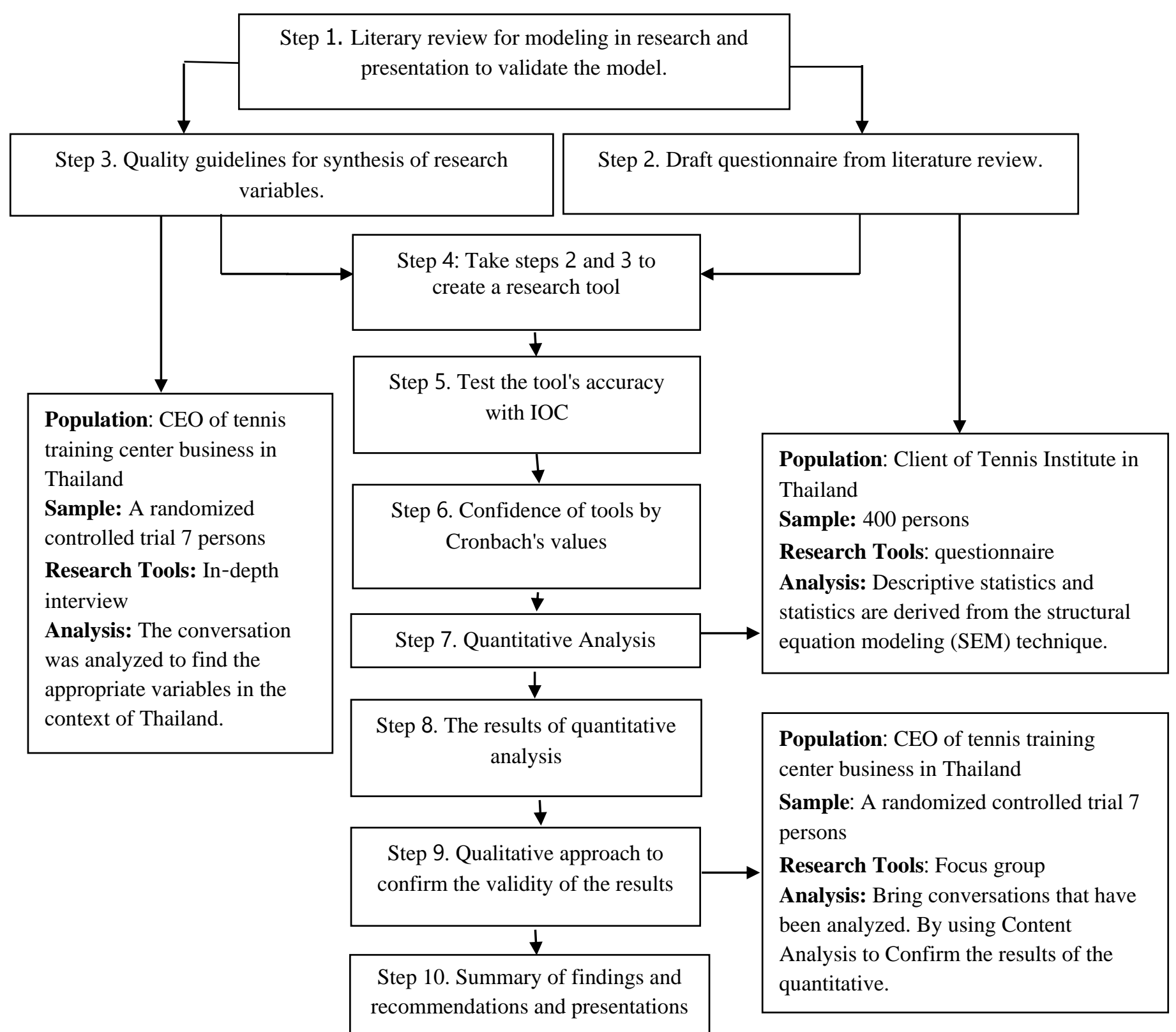

As the researcher has proposed a model for research, the next step in the research can be illustrated in Figure 5. The researcher will be able to present the results of the research. 


\section{REFERENCES}

David Teh Brian Corbitt. (2015). Building sustainability strategy in business, Journal of Business Strategy, Vol. 36 Iss 6 pp. $39-46$.

John Storey. (2007). Human Resource Management: A Critical Text (3rd Edition) Cengage Learning; 3 edition.

Johne, F. Axel And Snelson, Patricia A. (1988). Marketing's Role In Successful Product Development". Journal of Marketing Management.Vol.3 Issue 3, Spring, p. 256-268.

Johne, F. Axel And Snelson, Patricia A. (1988). Success Factors In Product Innovation, A Select Review Of The Literature. Journal of Product Innovation Management, Vol. 5, No. 2, p. 114-128.

Keelson Solomon A. (2012). The Evolution of the Marketing Concepts: Theoretically Different Roads Leading to Practically Same Destination, Online Journal of Social Sciences Research, Volume 1, Issue 2, pp. 35-41.2012.-hal. 35-41.

Kelly, D.T. (2000). The impact of the internal organizational environment on NSD, Knowledge management and NSD performance. (Unpublished Doctoral thesis, City University London).

Kittisombat source: http://www.dailynews.co.th/sports/526371, National Sports Development Plan Website: http://www.mots.go.th/more_news.php?cid=312.

McCarthy, E. J. (1964). Basic Marketing, IL: Richard D. Irwin.

Pairin (2013). Corporate Image of The Lawn Tennis Association of Thailand Under the Patronage of His Majesty, Degree of Master of Communication Arts School of Communication Arts, Sukhothai Thammathirat Open University.

Philip Kotler. (2000). Marketing management: Analyzing consumer marketing and Buyer behavior (The Millennium). New Jersey: Prentice Hall.

Poompitak (2017). Effects of Tennis 10s Training Program on Basic Sports Skills Tennis and agility in tennis players aged 4 - 6 years. Degree of Master Khonkaen University.

Pyke (1991). Coaching Excellence Champaign, Ill.: Human Kinetics, 2013, 272 pp. ISBN: 978-1-4504-2337-3.

Suphit, Samahito, et al, 2004The development of professional athletes under the support and promotion of the public and private sectors: A case study of professional tennis and professional football., Pitat Journal \# 19.

Thanaphan Naipinit, Somkier Kojchavivong, Vorawit Kowittayakorn \& Thongphon Promsaka Na Sakolnakorn. (2014). McKinsey 7S Model For Supply Chain Management of Local SMEs Construction Business In Upper Northeast Region of Thailand. Asian Social Science; Vol. 10, No. 8; 2014.

Wright, P.M., \& Mcmahan G.C., (1992). Theoretical Perspective for Strategic Human Resource Management. Journal of Management, 18(2), 295-320. 